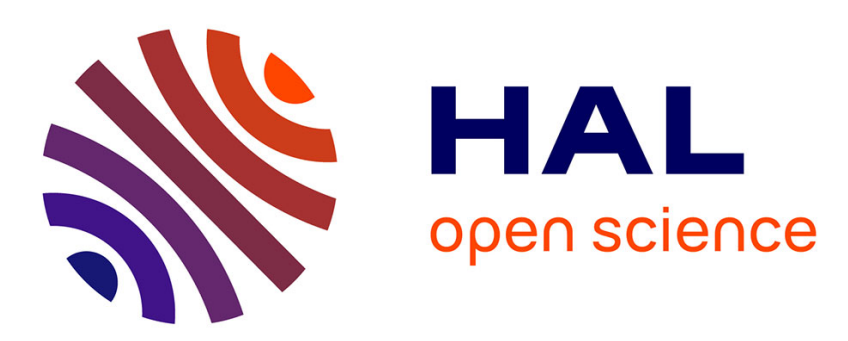

\title{
Management of a Proton Exchange Membrane Fuel Cell System to Feed a Superconducting Coil
}

Rafael-Antonio Linares-Lamus, Kévin Berger, Melika Hinaje, Bernard Davat

\section{To cite this version:}

Rafael-Antonio Linares-Lamus, Kévin Berger, Melika Hinaje, Bernard Davat. Management of a Proton Exchange Membrane Fuel Cell System to Feed a Superconducting Coil. IEEE Transactions on Applied Superconductivity, 2016, 26 (3), pp.0500804. 10.1109/TASC.2016.2535156 . hal-01275019

\section{HAL Id: hal-01275019 https://hal.science/hal-01275019}

Submitted on 19 Feb 2016

HAL is a multi-disciplinary open access archive for the deposit and dissemination of scientific research documents, whether they are published or not. The documents may come from teaching and research institutions in France or abroad, or from public or private research centers.
L'archive ouverte pluridisciplinaire $\mathbf{H A L}$, est destinée au dépôt et à la diffusion de documents scientifiques de niveau recherche, publiés ou non, émanant des établissements d'enseignement et de recherche français ou étrangers, des laboratoires publics ou privés. 


\title{
Management of a Proton Exchange Membrane Fuel Cell System to Feed a Superconducting Coil
}

\author{
Rafael Linares, Kévin Berger, Melika Hinaje, and Bernard Davat, Member, IEEE
}

\begin{abstract}
Proton Exchange Membrane Fuel Cells (PEMFC) and Superconducting Coils (SC) are electrical devices which give us a large number of possibilities in the applied research domains. We know that PEMFCs are used as alternative power supplies that convert hydrogen and oxygen redox reaction into electrical energy. This is a clean power source that produces only water and heat as waste. While the PEMFC can produce an important current density $\left(0.5 \mathrm{~A} / \mathrm{cm}^{2}\right.$ to $\left.1 \mathrm{~A} / \mathrm{cm}^{2}\right)$ in a dedicated working zone, its voltage is too small and needs to be conditioned by power electronics to make it suitable for use in electrical systems. In addition, the superconducting coils are used to produce strong magnetic fields, with less energy, at cryogenic temperature, e.g. the temperature of liquid Helium. Their main applications are in Magnetic Resonance Imaging (MRI) devices or in embedded systems. In order to create these magnetic fields, the SC require special kinds of power supplies capable of providing high current at low voltage. Usually, these power supplies generate non negligible harmonics. In this paper, we propose a solution for overcoming these problems. Indeed, we are working on a system that uses a PEMFC as an autonomous power supply for SC. The PEMFC will replace a high current power supply and it fits perfectly as an alternative energy supply for such systems, with the benefit of zero harmonic pollution. A model dedicated to a set of a superconducting coil fed by a PEMFC is reported. The inherent problems in connecting these two devices and some solutions to ensure the proper energy management are also given.
\end{abstract}

Index Terms-Ideal current source, Power converters, Power supply, Proton Exchange Membrane Fuel cell, Superconducting coils.

\section{INTRODUCTION}

$\mathrm{T}$ HE fuel cell is an important device, for the future of the energy management [1]. As a known way to store the energy, the hydrogen needs to find more systems that open his rentable use as soon as possible [2], [3]. Moreover, the expectations for the energy storage are concentrated in the research on the production of hydrogen, so the ways of production have been enhanced significantly [4]. The use of PEMFC as power supply has several disadvantages. Indeed, power converters are needed to manage and to make its electrical signal suitable for use, and in case of transient solicitations, storage devices such as batteries and supercapacitors are essentials. All these constraints add

This work was supported by ICEEL.

Rafael Linares, Kévin Berger, Melika Hinaje and Bernard Davat are with the Groupe de Recherche en Electrotechnique et Electronique de Nancy, Faculté des Sciences et Technologies, Université de Lorraine, 54506 Vandoeuvre-lès-Nancy, France (e-mail: rafael-antonio.linares-lamus@univlorraine.fr; kevin.berger@univ-lorraine.fr; melika.hinaje@univ-lorraine.fr; bernard.davat@univ-lorraine.fr).

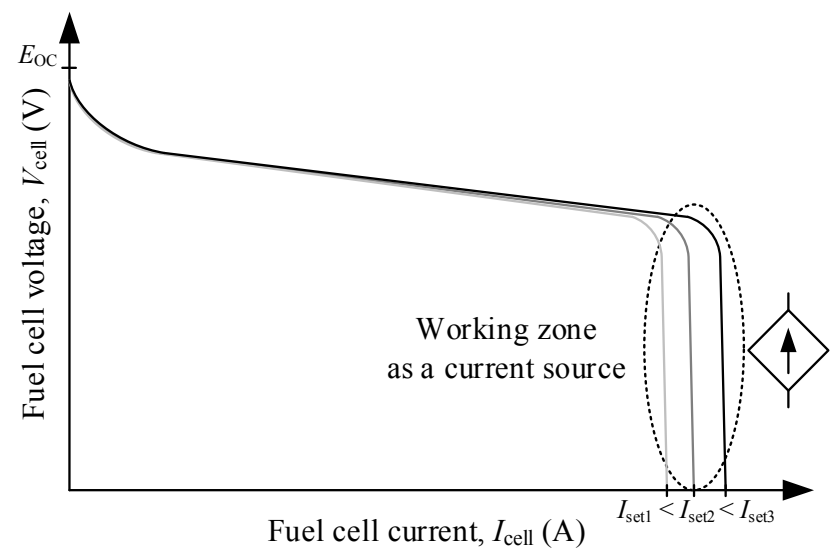

Fig. 1. Polarization curve of the PEMFC and its working zone as a current source.

additional cost, and increases the congestion [5]. Hence we have worked in the development of a system without the need to use complex power electronics converters or other devices.

The aim is to take advantage of the low voltage and high DC current free of ripples of the PEMFC that fit the criteria of the power supplies used for the Superconducting Coils (SC). The current ripple and current stability for these power supplies are generally around 10 to $100 \mathrm{ppm}$ [6], [7].

Therefore, these characteristics make suitable the devices for working together. This opens a new and revolutionary use of the PEMFC as a power supply for superconducting devices. However, the need remains to use power electronics as an apparatus able to protect the both systems, but this one is less complex than the classic power electronics converters used.

In [8], the PEMFC was connected directly with a supercapacitor and showed its ability to work in short circuit for a short time. This mode of functioning is similar to a controlled current source. Fig. 1 shows a typical polarization curve of the PEMFC and its working zone as a current source. Within this mode, the fuel cell current $I_{\text {cell }}$ can be directly controlled by using the hydrogen flow rate $d_{\mathrm{H} 2}$, through a reference current $I_{\text {set }}$, as shown in (1). In other words, $I_{\text {set }}$ is the fuel cell current set point.

$$
\left\{\begin{array}{l}
d_{\mathrm{H}_{2}}=I_{\text {set }} \frac{1}{2 P_{0}} \frac{R T_{0}}{F} \cdot \zeta_{\mathrm{a}} \cdot 1000 \cdot 60 \quad\left(\mathrm{~L} \cdot \mathrm{min}^{-1}\right) \\
d_{\text {air }}=I_{\text {set }} \frac{1}{4 P_{0}} \frac{R T_{0}}{F} \frac{1}{0.21} \cdot \zeta_{\mathrm{c}} \cdot 1000 \cdot 60 \quad\left(\mathrm{~L} \cdot \mathrm{min}^{-1}\right)
\end{array}\right.
$$

where $R$ is the gas constant: $8,3144621 \mathrm{~J} \cdot \mathrm{mol}^{-1} \cdot \mathrm{K}^{-1}$, $T_{0}$ is the gas temperature: $298.15 \mathrm{~K}$,

$F$ is the Faraday's constant: $96485.33289 \mathrm{C} \cdot \mathrm{mol}^{-1}$,

$P_{0}$ is the gas pressure: $101325 \mathrm{~Pa}$,

$\zeta_{\mathrm{a}}$ and $\zeta_{\mathrm{c}}$ are the anode and cathode stoichiometric coefficients. 
To ensure the current control, as in a current source: $\zeta_{\mathrm{a}}=1$ and $\zeta_{\mathrm{c}}=4$.

In a previous experimental part [9], we have worked in the direct coupling between a PEMFC and an SC. We were able to verify experimentally that the PEMFC could work as a current supply. The $\mathrm{SC}$ resistance is almost zero, thus it can be considered as a short circuit for the current supply. First of all, the PEMFC anode and cathode were directly connected by means of a short wire, so the PEMFC was short-circuited. This experiment reveals the current source behavior of the PEMFC. Moreover, it confirms that the PEMFC current can be controlled by hydrogen flow rate. The next step, was to connect directly the PEMFC to a small SC with a low inductance value of $4 \mathrm{mH}$. This connection has worked properly during the different tests. However, this case does not represent most of the superconducting devices, for which the inductance value is usually higher, from a few Henry to several tens of Henry [10]. Hence, it is important to study such systems with high values of inductance and to test them experimentally. Indeed, the PEMFC could react in a different way with a coil of high inductance as load.

Additional studies will also need to be performed to test the degradation of the membrane, when the PEMFC is working as a current source, Fig. 1.

This paper represents the next step of the PEMFC - SC system design. Hence, we have worked to enhance the PEMFC model to be able to feed a real $\mathrm{SC}$ with a high value of inductance. We focused on the effects of this inductance value in the performances of the PEMFC. Then, to complete the design of the experimental test bench, the protection device will need to be sized.

\section{MODELLING OF THE SYSTEM}

\section{A. Method}

The entire system model is built with Matlab Simulink. This model has two elements: the PEMFC and the SC. The characteristic equations of each element were adapted into the software language and the parameters used to define the model are shown in Table I. These parameters allow the PEMFC to operate as a current supply with a control of the current by the hydrogen flow rate.

The model used for the SC is that of a classical inductor represented by a perfect inductance $L_{\mathrm{SC}}$ with a small resistance $R_{\text {wire }}$ in series. This latter represents the resistance of the wire used to connect the PEMFC to the SC.

The model of the whole system has been validated by means of the experimental results obtained for a superconducting coil of $4 \mathrm{mH}$ connected by a wire of $4 \mathrm{~m} \Omega$ to a PEMFC with an active area of $100 \mathrm{~cm}^{2}$.

Then, several simulations have been performed, where the inductance value has taken several values from $1 \mathrm{H}$ to $10 \mathrm{H}$. The value of the resistance in series has also been changed in order to calculate the maximum length of wire between the $\mathrm{PEMFC}$ and the $\mathrm{SC}$ required to perform the experimental test.

\section{B. Fuel cell model}

In this paper, the PEMFC model shown in Fig. 2 is an
TABLE I

PARAMETERS USED IN THE Fuel Cell MODEL

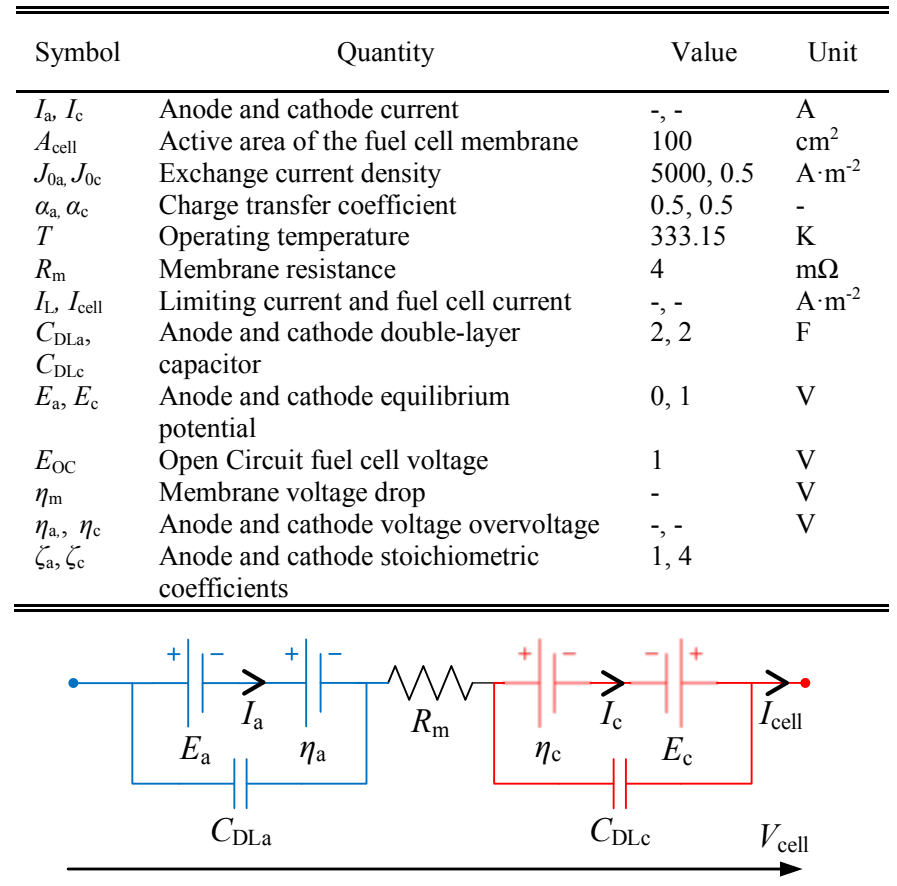

Fig. 2. Electric dynamic model of a single PEM fuel cell.

electrical one, where the values of the elements come from the mass and charge transfer phenomena that occur in the PEMFC. It should be noted that the PEMFC model used in this paper is a 1D model, which does not include some physical aspects as the gas distribution in the channels and the gas pipes.

The faradic currents $I_{\mathrm{a}}$ and $I_{\mathrm{c}}$ are computed using the set of coupled equations (2) to (7):

$$
\begin{aligned}
& I_{\mathrm{a}}=A_{\text {cell }} J_{0 \mathrm{a}}\left(\exp \left(2 \alpha_{\mathrm{a}} f \eta_{\mathrm{a}}\right)-\exp \left(-2\left(1-\alpha_{\mathrm{a}}\right) f \eta_{\mathrm{a}}\right)\right) \\
& \text { with } f=\frac{F}{R T} \\
& \eta_{\mathrm{a}}=\frac{1}{f} \operatorname{argsh}\left(\frac{I_{\mathrm{a}}}{2 A_{\text {cell }} J_{0 \mathrm{a}}}\right) \\
& I_{\mathrm{c}}=A_{\text {cell }} J_{0 \mathrm{c}}\left(\left(1-\frac{I_{\mathrm{c}}}{I_{\mathrm{L}}}\right) \exp \left(2\left(1-\alpha_{\mathrm{c}}\right) f \eta_{\mathrm{c}}\right)\right) \\
& \eta_{\mathrm{c}}=\frac{1}{f} \ln \left(1+\frac{\exp \left(-2 \alpha_{\mathrm{c}} f \eta_{\mathrm{c}}\right)}{I_{\mathrm{cell}} J_{0 \mathrm{c}}}\right)-\frac{1}{f} \ln \left(1-\frac{I_{\mathrm{c}}}{I_{\mathrm{L}}}\right) \\
& I_{\mathrm{a}, \mathrm{c}}=I_{\text {cell }}-C_{\mathrm{DLa}, \mathrm{c}} \frac{d}{d t} \eta_{\mathrm{a}, \mathrm{c}} \\
& V_{\text {cell }}=\left(E_{\mathrm{c}}-\eta_{\mathrm{c}}\right)-\eta_{\mathrm{m}}-\left(E_{\mathrm{a}}+\eta_{\mathrm{a}}\right)
\end{aligned}
$$

where $I_{\mathrm{L}}$ is the limiting current of the fuel cell. It corresponds to the maximum current that can flow through the fuel cell, and depends on gas supply.

Thus, the described PEMFC model is able to perform some simulations with an SC as load. Equations (2) to (7) can reproduce the PEMFC behavior in these conditions. 


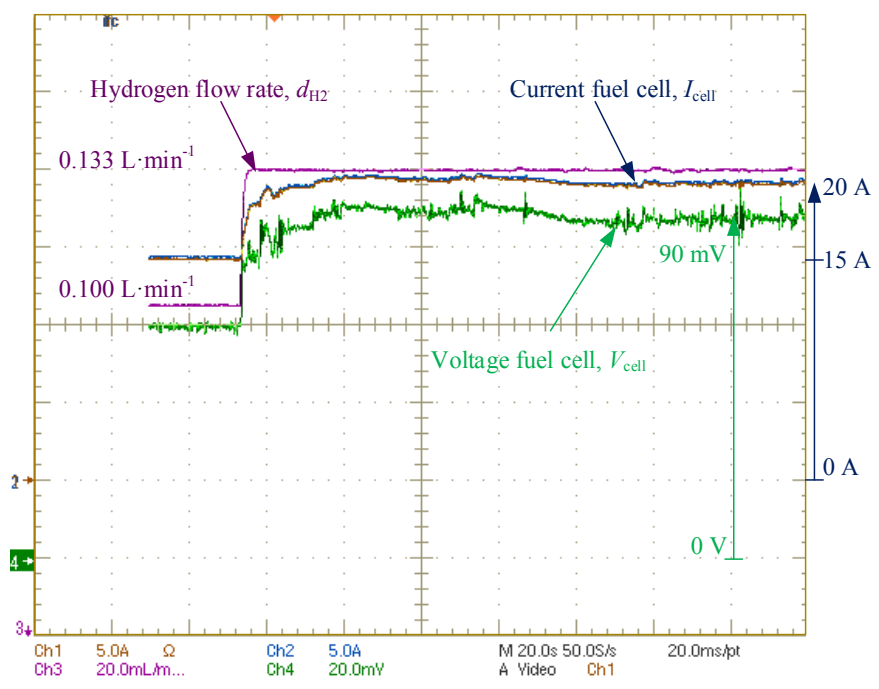

Fig. 3. Experimental results obtained with a PEMFC connected by a wire of $4 \mathrm{~m} \Omega$ to a superconducting coil of $4 \mathrm{mH}$. Response to a step of the hydrogen flow rate from 0.100 to $0.133 \mathrm{~L} \cdot \mathrm{min}^{-1}$ corresponding to a step of $I_{\text {set }}$ from 15 to $20 \mathrm{~A}$.

\section{Superconducting coil model}

The resistance of an SC is zero, so the model used to represent the $\mathrm{SC}$ is a perfect inductance $L_{\mathrm{SC}}$. However, the resistance of the wire $R_{\text {wire }}$ used to connect the PEMFC to the $\mathrm{SC}$ in series must be taken in consideration. The parasitic capacitance of the $\mathrm{SC}$ has been neglected. As a result, when the PEMFC and the SC are connected together, the fuel cell voltage $V_{\text {cell }}$ can be expressed as:

$$
V_{\text {cell }}(t)=R_{\text {wire }} I_{\text {cell }}(t)+L_{S C} \frac{d}{d t}\left(I_{\text {cell }}(t)\right)
$$

The set of equations (2) to (8) is used to calculate $I_{\text {cell }}$ and $V_{\text {cell. }}$

\section{Validation of the model}

We need to confirm if the developed PEMFC model coupled with an SC works correctly.

Therefore, an experimentation has been done with a PEMFC connected by a wire of $4 \mathrm{~m} \Omega$ to a superconducting coil of $4 \mathrm{mH}$. A simulation was made to confirm that the PEMFC-SC model could be used to predict the behavior of the real system.

Fig. 3 shows the experimental results of a PEMFC connected by a wire of $4 \mathrm{~m} \Omega$ to a superconducting coil of $4 \mathrm{mH}$. The responses of the voltage and the current of the fuel cell to a step of the hydrogen flow rate from 0.100 to $0.133 \mathrm{~L} \cdot \mathrm{min}^{-1}$ corresponding to a step of $I_{\text {set }}$ from 15 to $20 \mathrm{~A}$ are represented. $I_{\text {cell }}$ behaves as a first order and reaches the target value in $28 \mathrm{~s}$. The hydrogen flow rate follows the fuel cell current set point $I_{\text {set. }}$. This confirms the hypothesis of the current control through the hydrogen flow rate when the PEMFC is connected to a low resistance or short-circuited.

Fig. 4 shows the simulation results with the parameters corresponding to the experiment shown in Fig. 3. The behavior of the PEMFC has been reproduced thanks to the simulation. We emphasize that $I_{\text {cell }}$ takes less time to reach the target value. This can be explained by the assumptions done in

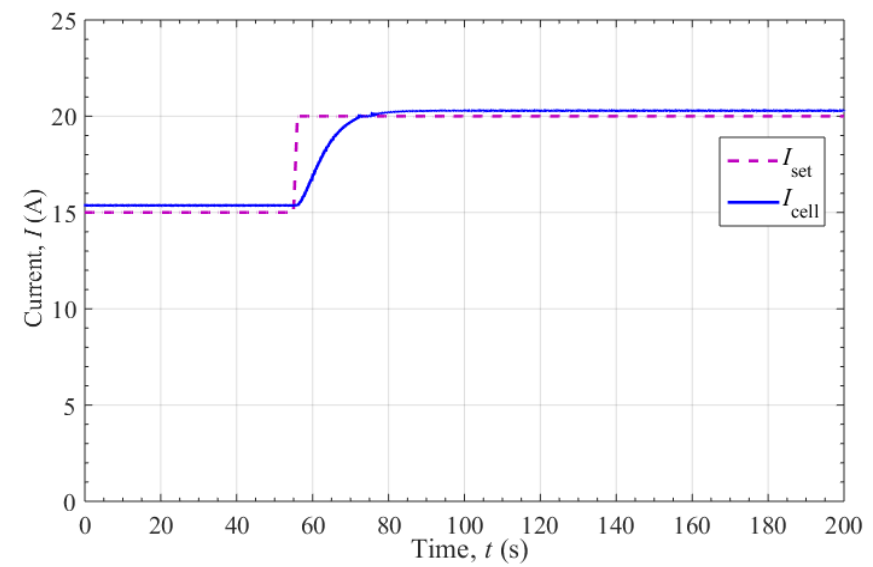

Fig. 4. Simulated current $I_{\text {cell }}$ of the fuel cell obtained with a PEMFC connected by a wire of $4 \mathrm{~m} \Omega$ to a superconducting coil of $4 \mathrm{mH}$. Response to a step of $I_{\text {set }}$ from 15 to $20 \mathrm{~A}$.

the 1D model. However, we can see that the PEMFC model gives qualitative results, which are sufficient to validate the model. Some of the experimental values are hard to determine with accuracy, and separately for each electrodes, such as the double-layer capacitors $C_{\mathrm{DLa}, \mathrm{c}}$, this can explain any differences between the results.

\section{RESULTS AND DISCUSSION}

The connection of a PEMFC with an SC is totally new and has been simulated with success in Section II.

As we will see in this section, it might happen a resonance between the double-layer capacitors $C_{\mathrm{DLa}, \mathrm{c}}$ and the $\mathrm{SC}$ inductance $L_{\mathrm{SC}}$. This resonance depends on the value of the inductance of the SC and leads to some ripples of the fuel cell current.

As mentioned in Section I, the superconducting devices may have inductance value of several tens of Henry. In the following simulations, the inductance value of the SC has been set to $10 \mathrm{H}$ while the resistance of the wire is kept at $4 \mathrm{~m} \Omega$.

In Fig. 5, the simulated response of the fuel cell current $I_{\text {cell }}$ to a step current $I_{\text {set }}$ from 0 to $20 \mathrm{~A}$ is presented. Without a dedicated management, some ripples are observed on $I_{\text {cell }}$ in the Steady State (SS) and the fuel cell voltage takes some negative values. Those current ripples are undesirable and can lead to additional losses in the SC. However, the amplitude of the current oscillations, of around $1 \%$, observed in Fig. 5, are not sufficient to generate important losses. The most important damage might be the ripples observed in the fuel cell voltage $V_{\text {cell. }}$. Indeed, some negative values of $V_{\text {cell }}$ lead to irreversible damage to the PEMFC. Thus, the need to control these oscillations is also important in order to protect the PEMFC from being submitted to a reverse voltage.

It has been highlighted in Fig. 5 that the PEMFC current $I_{\text {cell }}$ slowly follow the current set point $I_{\text {set. }}$. This result is mainly due to the high value of the SC inductance and to the low voltage that can deliver a single PEMFC. The Transient State (TS) of $I_{\text {cell }}$ is characterized by a quasi-linear increase from 0 to $20 \mathrm{~A}$ and a time constant of $280 \mathrm{~s}$. To reduce this TS, a stack of fuel cell, i.e. several cells in series, can be used. In 


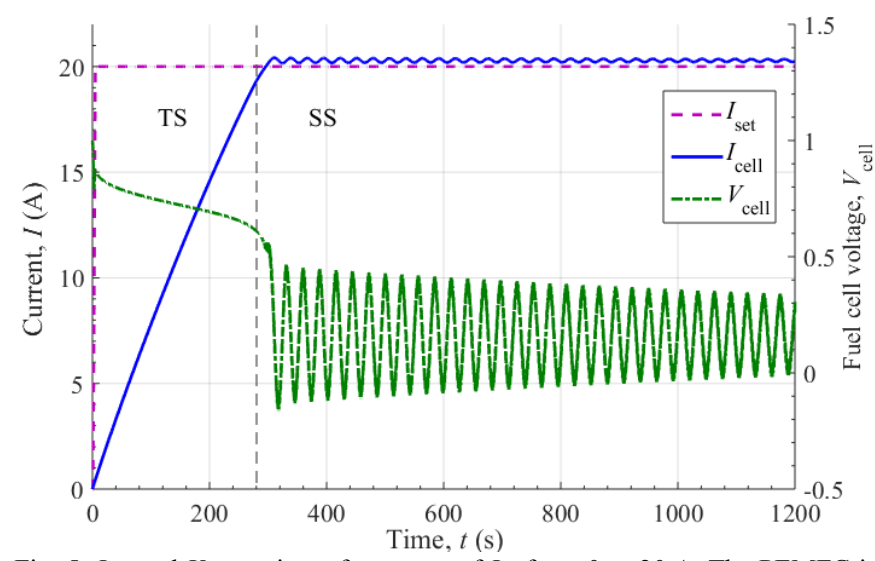

Fig. 5. $I_{\text {cell }}$ and $V_{\text {cell }}$ vs time after a step of $I_{\text {set }}$ from 0 to $20 \mathrm{~A}$. The PEMFC is connected through a wire of $4 \mathrm{~m} \Omega$ to an SC of $10 \mathrm{H}$. Without a dedicated management, some current ripples exist in the Steady State (SS) and the fuel cell voltage takes some negative values.

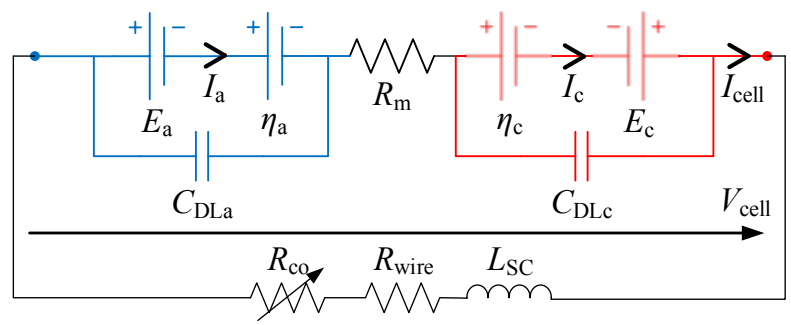

Fig. 6. Electric dynamic model of a single PEM fuel cell connected to an SC. The variable resistor $R_{\text {co }}$ allows to manage the ripples in the fuel cell current.

any case, the SC needs to be fed slowly to avoid its quench.

The resistance of the load connected to the PEMFC, $R_{\text {wire }}$ in the studied case, has an influence on the ripples of the current $I_{\text {cell }}$ in the SS. Therefore, we propose to use a variable resistor $R_{\mathrm{co}}$ in series with the $\mathrm{SC}$ in order to control the current ripples. The values will be adapted in the SS of the current $I_{\text {cell. }}$.

The $I_{\text {cell }}$ and $V_{\text {cell }}$ responses to a step of $I_{\text {set }}$ from 0 to $20 \mathrm{~A}$ are shown again in Fig. 7, but this time the proposed management by using $R_{\mathrm{co}}$ is activated. During the TS, the value of $R_{\mathrm{co}}$ is kept to zero in order to preserve the rise rate of the current $I_{\text {cell. }}$. It seems that the value of $23 \mathrm{~m} \Omega$ for the control resistor $R_{\mathrm{co}}$, applied in the SS at $t=280 \mathrm{~s}$, leads to a total reduction of the ripples of the current $I_{\text {cell }}$ and to an accurate value for $I_{\text {cell }}$ of $20 \mathrm{~A}$. A higher value of $R_{\text {co }}$ prevents the current from reaching the $I_{\text {set }}$ value.

Consequently, the need of a control system is obvious. This latter cancels the ripples of the desired current in the SC and prevents the PEMFC from an accidental damage.

Therefore, the realization of a system composed of a PEMFC as current supply and a superconducting device as load is highly possible. There are a series of others factors that need to be solved to secure the both devices to perform the experimental test but they do not depend on their connection together.

\section{CONCLUSION}

The first objective of this work was to simulate a fuel cell model as current source, used to feed a superconducting coil. A dedicated PEMFC model has been verified by using the experimental results obtained for a small inductance coil of

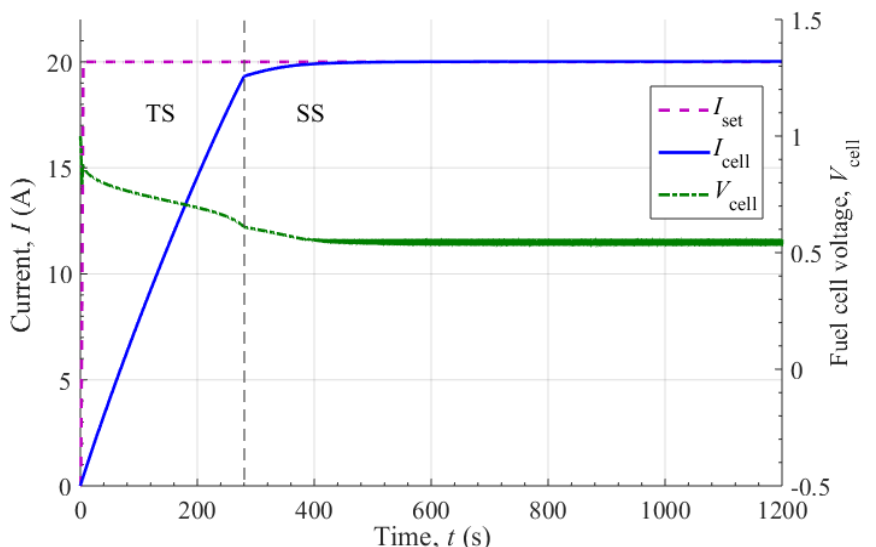

Fig. 7. $I_{\text {cell }}$ and $V_{\text {cell }}$ vs time after a step of $I_{\text {set }}$ from 0 to $20 \mathrm{~A}$. The PEMFC is connected through a wire of $4 \mathrm{~m} \Omega$ to an SC of $10 \mathrm{H}$. By adjusting $R_{\mathrm{co}}$ to $23 \mathrm{~m} \Omega$ after the Transient State (TS) at $t=280 \mathrm{~s}$ ), the current ripples are suppressed and the fuel cell voltage is always positive.

$4 \mathrm{mH}$. Other simulation results have shown that an $\mathrm{SC}$ of $10 \mathrm{H}$ can generate undesirable ripples in the fuel cell current. Hence, a PEMFC connected directly to such an SC is not suitable. However, we have shown that the fuel cell current can be managed by using a simple variable resistor in series with the SC, i.e. without power converters.

Therefore, the realization of a system composed of a PEMFC as a current supply and a superconducting device as load is highly possible. There are a series of others factors that need to be solved to secure the both devices, but they do not depend on their connection together.

For the next step in this new PEMFC application, the experimental set with an $\mathrm{SC}$ of $10 \mathrm{H}$ will be made.

\section{REFERENCES}

[1] M. C. Williams, "Fuel cells and the world energy future," in Proc. IEEE-PES Summer Meeting, Vancouver, BC, Canada, 2001, pp. 725730.

[2] A. Al-Ahmed, S. Hossain, B. Mukhtar, S. U. Rahman, H. Abualhamayel, and J. Zaidi, "Hydrogen highway: An overview," in Energy Conference and Exhibition (EnergyCon), 2010 IEEE International, 2010, pp. 642-647.

[3] S. Vazquez, S. Lukic, E. Galvan, L. G. Franquelo, J. M. Carrasco, and J. I. Leon, "Recent advances on Energy Storage Systems," in IECON 2011 - 37th Annual Conference on IEEE Industrial Electronics Society, 2011, pp. 4636-4640.

[4] B. Yue, Q. Li, H. Iwai, T. Kako, and J. Ye, "Hydrogen production using zinc-doped carbon nitride catalyst irradiated with visible light," Sci. Technol. Adv. Mater., vol. 12, no. 3, p. 034401, 2011.

[5] X. Kong, L. T. Choi, and A. M. Khambadkone, "Analysis and control of isolated current-fed full bridge converter in fuel cell system," in IECON 2004 - 30th Annual Conference of IEEE Industrial Electronics Society, 2004, vol. 3, pp. 2825-2830.

[6] "Model 430 from AMI." [Online]. Available: http://www.americanmagnetics.com/brochures/model430.pdf. [Accessed: 29-Dec-2015].

[7] "MercuryiPS from Oxford Instruments." [Online]. Available: http://www.oxford-

instruments.com/OxfordInstruments/media/nanoscience/PDFs/Instrumen tation/Mercury-Instrumentation-Product-Guide.pdf. [Accessed: 29-Dec2015].

[8] M. Hinaje, S. Raël, J.-P. Caron, and B. Davat, "An innovating application of PEM fuel cell: Current source controlled by hydrogen supply," Int. J. Hydrog. Energy, vol. 37, no. 17, pp. 12481-12488, Sep. 2012.

[9] M. Hinaje, K. Berger, J. Lévêque, and B. Davat, "Using Fuel Cell as a Power Supply for Superconducting Coil," IEEE Trans. Appl. Supercond., vol. 24, no. 6, pp. 1-6, Dec. 2014. 
[10] P. Vedrine, G. Aubert, F. Beaudet, J. Belorgey, C. Berriaud, P. Bredy, A. Donati, O. Dubois, G. Gilgrass, F. P. Juster, C. Meuris, F. Molinie, F. Nunio, A. Payn, T. Schild, L. Scola, and A. Sinanna, "Iseult/INUMAC Whole Body 11.7 T MRI Magnet Status," IEEE Trans. Appl. Supercond., vol. 20, no. 3, pp. 696-701, Jun. 2010. 